\title{
TITULARIDAD Y NATURALEZA JURIDICA DEL MONTE «VALLERRUTAJO»
}

352.711

por

\author{
Rafael Nasarre Alastruey \\ Secretario general de la Diputación Provincial de La Rioja
}

SUMARIO: I. INTRODUCCION.-II. ANTECEDENTES: 1. EvOLUCIÓN JURÍDICO-ADMINISTRATIVA DEL MONTE. 2. TRAMITES REALIZAdos para la CESIÓN DEL MONTE a La Diputación Provincial.III. NATURALEZA JURIDICA DEL MONTE «VALLERRUTAJO»: 1. DeRIVAda de SU inClusión en el Catálogo. 2. EN Razón A SU PERTENENCIA: A) Inclusión en el Catálogo de 1901. B) Fusión de los citados Municipios. C) Administración del monte a partir de 1930. D) Inscripción en el Registro de la Propiedad. E) Afirmación de los vecinos de Carbonera de que el monte es "vecinal en mano común». F) Inclusión en el Catálogo de 1977. 3. PoR RAZÓN DE SU DESTINO O APROVECHAMIENTO: A) Vicisitudes hasta la década de los años sesenta. B) Destino del monte hasta nuestros dias.-IV. EXAMEN DE LAS ACTUACIONES ADMINISTRATIVAS HABIDAS A PARTIR DEL EXPEDIENTE DE FUSION: 1. INSCRIPCIÓN DEL MONTE EN EL REgISTRO DE LA PROPIEDAD. 2. Resolución DEL Ministerio de Agricultura DE 1 DE SEPTIEMBRE DE 1961: A) Argumentos de Carbonera. B) Argumentos de la Abogacía del Estado. C) Argumentos de la Jefatura del Distrito Forestal. 3. CESIÓN DEL MONTE a LA Diputación Provincial. 4. Pertenencia o titularidad del monte según el Catálogo DE 1977. 5. INCLUSIÓN DEL MONTE EN EL INVENTARIo DE BIENES DE 
la Diputación.--V. SOluCiONES QUE SE PROPONEN: 1. ProCEDIMIENTO PARA MODIFICAR LA TITULARIDAD O PERTENENCIA DEL MONTE: A) En el Catálogo de Montes de Utilidad Pública. B) En el Registro de la Propiedad. C) En el Inventario de Bienes de la Diputación. 2. OPcIONES POSTERIORES: A) Desafectación o no del carácter comunal del monte. B) Destino del monte.-VI. CONCLUSIONES.

\section{INTRODUCCION}

Los vecinos de la aldea o lugar de Carbonera, Municipio de Bergasa, de la Provincia de La Rioja, cedieron a la Diputación en 1976 el monte conocido por «Vallerrutajo». Dificultades habidas a la hora de formalizar en escritura dicha cesión han motivado el presente estudio, que trata de contestar a diversas preguntas relacionadas con la naturaleza jurídica del monte, con su titularidad dominical y con la procedencia o no de la cesión indicada, así como de ofrecer posibles soluciones a la situación planteada.

\section{ANTECEDENTES}

1. EVOLUCIÓN JURÍDICO-ADMINISTRATIVA DEL MONTE

El dato más antiguo que poseemos del monte es su inscripción en el Catálogo de Montes de Utilidad Pública, aprobado por Real Decreto de 1 de febrero de 1901, donde aparece registrado al número 4 y en el que, con una cabida de 446 hectáreas, se asignaba su pertenencia "al pueblo de Carbonera».

En dicho documento -página 445 de la publicación oficialse observa también que nueve de los diez montes que aparecen en él tienen asignada su pertenencia «al pueblo de...», siendo éste el correspondiente al término municipal donde está situado cada monte.

En 1930 se inicia expediente de fusión de los Municipios de Bergasa y Carbonera, cuyos trámites esenciales son los siguientes:

a) Petición del Ayuntamiento de Carbonera el 16 de enero de 1930, de conformidad con lo dispuesto en los artículos 17 y $18 \mathrm{del}$ Estatuto Municipal («toda vez que no pueden continuar levantando 
las cargas municipales que sobre los vecinos pesan»), en el sentido de que:

- «ea la Villa Bergasa la capitalidad del Municipio.»

- «Las deudas actuales de cada Municipio y los créditos contraídos respondan cada cual hasta que sean saldados, pasando entonces a mancomunarse los que se presenten.»

- «La administración de los bienes patrimoniales de ambos Municipios será por el de la capitalidad, de conformidad con los Estatutos que al efecto se formen con las estipulaciones entre los mismos respecto a obligaciones, derechos e intereses de cada uno a fin de evitar conflictos posteriores.»

Dicha petición la ratifican después los vecinos de Carbonera a su propio Ayuntamiento, en escrito de 10 de abril de 1930.

b) El Ayuntamiento de Bergasa, en sesión extraordinaria de 26 de enero de 1930, acuerda por unanimidad dar principio al expediente de fusión, como determina el Reglamento de Población y Términos Municipales de 1924.

c) Redactados los Estatutos, son aprobados el 23 de febrero de 1930. Consta de 14 artículos, de los que destacamos los siguientes:

«Art. 1.ं Será de la exclusiva competencia del Ayuntamiento de Bergasa la observancia de las leyes y aplicación de las mismas de conformidad a lo dispuesto por el artículo 150 del Estatuto Municipal vigente $\mathrm{y}$ dentro del mismo y siguientes, la fusión establecida en esta forma.

Art. 2. Los Ayuntamientos respectivos se comprometen al servicio de fusión de toda clase de pastos y su aprovechamiento, sin derecho a reclamación, pagando cada uno los pastos que afecten a ellos.»

d) La fusión acordada se publica en la Gaceta de Madrid, número 35, de 5 de febrero de 1931.

A partir de la fusión, y sin que aparezca concretada la fecha, se constituye en la aldea de Carbonera una Junta Administrativa, compuesta del Presidente o Alcalde pedáneo y dos Vocales, que actúa en representación de dicha aldea, como si realmente ésta estuviera constituida en Entidad local menor. De hecho, incluso, a la vista de determinados escritos, parece que se ignora dicha fusión por el Distrito Forestal y aun por la propia Entidad de Carbonera, o se reconoce la existencia de la Entidad local menor por algunos Ayuntamientos. En cualquier caso, la Junta administra 
los bienes de Carbonera -cuyos aprovechamientos principales son leñas y pastos-, dando cuenta de esta administración a los vecinos de la aldea.

En 1953, 24 vecinos de Carbonera solicitan constituirse en Entidad local menor, con fundamento en tener parroquia, escuela, Juez municipal y Hermandad Sindical de Labradores. El Consejo de Ministros, en su reunión de 15 de enero de 1955, desestima la petición aduciendo: que la parroquia está atendida por el Cura párroco de Tudelilla; el Juzgado de Paz está suspendido; la Hermandad de Labradores no tiene misión concreta; «los bienes de propios con que cuenta Carbonera no son suficientes para el cumplimiento independiente de sus fines», y la oposición de Bergasa daría lugar a una constante disensión y malestar entre ambos pueblos, tanto en el orden económico como en el social.

El Registrador de la Propiedad de Arnedo, con base en certificación expedida por el Ingeniero Jefe de Montes del Distrito Forestal de Logroño de fecha 21 de octubre de 1960, a petición de la Alcaldía pedánea de Carbonera, inscribe a favor del pueblo de Carbonera el monte Valle Rutajo, al amparo de los artículos 206 de la Ley Hipotecaria y 11 de la Ley de Montes de 8 de junio de 1957.

El Ministerio de Agricultura, mediante resolución de 1 de septiembre de 1961, desestima instancia del Ayuntamiento de Bergasa en la que, con motivo de la fusión, se solicitaba el cambio a su nombre de la inscripción que, del repetido monte, existía en el Catálogo a favor del pueblo de Carbonera. Los considerandos de dicha resolución se basan en los argumentos de Carbonera y, principalmente, en los informes de la Abogacía del Estado y de la Jefatura del Distrito Forestal.

El Gobierno Civil de la Provincia, mediante oficio número 201, de 25 de enero de 1962, comunica al Alcalde de Bergasa que "procede que por ese Ayuntamiento se adopten las resoluciones pertinentes para que toda la administración y demás actividades de este orden realizadas por Carbonera y en su nombre el Alcalde pedáneo, se integren en esa Corporación municipal, debiendo dicho Alcalde pedáneo cesar inmediatamente en el ejercicio de tal cargo (...); a cuyo efecto deberá levantarse acta-inventario de haberse hecho cargo el Ayuntamiento de la citada administración y bienes de la misma...", acta que fue levantada el 1 de marzo del mismo año.

A partir de dicha fecha apenas conocemos documentación alguna relacionada con los aprovechamientos o administración del mon- 
te. Sólo una relación de tales aprovechamientos, suscrita por el Ayuntamiento de Bergasa, fechada el 26 de marzo de 1963, que permite suponer que este Ayuntamiento tenía a su cargo ya dicha administración.

Entre 1963 y 1964 hay un intento por parte del Ayuntamiento de Bergasa para recuperar la titularidad del monte, cuyas actuaciones más importantes son las siguientes:

a) Demanda ante el Juzgado de Primera Instancia de Arnedo.

b) Sentencia de este Juzgado de 22 de febrero de 1964, por la que, en base al artículo 11 de la Ley de Montes de 8 de junio de 1957 y al artículo 57-2 de la Ley de 14 de octubre de 1882, adicional a la orgánica del poder judicial, declara improcedente la excepción dilatoria número 7 del artículo 533; estima el defecto legal de falta de emplazamiento a la Abogacía del Estado, por lo que considera nulas las actuaciones hasta el momento procesal en que se encuentran, y declara competente al Juzgado de Primera Instancia de Logroño.

c) La Sala de lo Civil de la Audiencia Territorial de Burgos, mediante sentencia de 26 de septiembre de 1964, estima la excepción dilatoria de incompetencia de jurisdicción propuesta por los demandados, declarando competente al Juzgado de Logroño.

Por razones que desconocemos (¿falta de medios económicos?), el Ayuntamiento de Bergasa no insiste en su demanda ante el Juzgado de Primera Instancia de Logroño.

En 1976 se inicia el expediente de cesión del monte a la Diputación, cuyos trámites detallamos más adelante.

El Consejo de Ministros, por Real Decreto número 286/1977, de 21 de enero, aprueba el Catálogo de Montes de Utilidad Pública de la Provincia de Logroño, que aparece publicado en el Boletín Oficial del Estado número 54, de 4 de marzo.

En este Catálogo se asigna la pertenencia del monte Vallerrutajo, también registrado al número 4, a «Carbonera, lugar del Municipio de Bergasa".

La pertenencia de los 188 montes que integran el Catálogo se desglosa así: uno a cada una de las siguientes Entidades: "lugar», "entidad menor", "hermandad" y "Ayuntamiento y Comuneros", dos a "Comunidades»; cuatro a "aldeas»; siete a "Ayuntamientos y aldeas»; siete a ICONA; ocho a «Mancomunidades» y 156 a «Ayuntamientos». 
A partir de 1977, el citado Instituto concede los aprovechamientos del monte Vallerrutajo a la Diputación Provincial de Logroño.

2. Trámites realizados para la cesión del monte

a la Diputación Provincial

Cuatro vecinos de Carbonera (la totalidad de cabezas de familia avecindadas en la aldea), mediante escrito presentado en la Diputación el 9 de septiembre de 1976, no tienen inconveniente en ceder a esta Entidad el monte Vallerrutajo (calificado jurídicamente, según los vecinos, de "propiedad vecinal en mano común»), siempre que se destine «a la creación de un gran parque comarcal, del que carece la Rioja Baja, o a otra finalidad similar de interés público».

El Ayuntamiento de Bergasa, por acuerdo de 5 de octubre del mismo año, acuerda acceder a los deseos de dichos vecinos, "ya que son titulares del citado monte...».

La Corporación Provincial, en sesión de 27 de octubre de 1976, acuerda aceptar el ofrecimiento de los vecinos de Carbonera.

El expediente de cesión se expone al público en el Boletín Oficial de la Provincia número 136, de 27 de noviembre de 1976, sin que durante los quince días hábiles siguientes se presenten reclamaciones.

Mediante escrito de fecha 10 de octubre de 1977, el Ministro de Agricultura estima que "por su parte no existe inconveniente para que se lleve a cabo la cesión de la propiedad del meritado monte».

La Dirección General de Administración Local, en escrito de 17 de noviembre de 1977, participa que "no es competencia de este Ministerio el autorizar o dar su conformidad a la cesión de referencia».

Enviada la documentación correspondiente al Notario de Arneđo, para la formalización de la cesión en escritura pública, manifiesta por escrito de 9 de mayo de 1978 que «consultados al efecto los artículos 2 de la Ley de Montes y 182 y siguientes de su Reglamento, comunico a V. I. que no encuentro posibilidad alguna de que pueda llevarse a efecto tal cesión sin cumplir lo en ellos dispuesto, dado el carácter de catalogado de dicho monte».

El repetido monte aparece incluido por vez primera en el Inventario de Bienes de la Diputación referido al 31 de diciembre de 1977. 


\section{NATURALEZA JURIDICA DEL MONTE «VALLERRUTAJO»}

\section{Derivada de su inclusión en el Catálogo}

El Catálogo de Montes de Utilidad Pública ha tenido dos períodos claramente diferenciados:

El primero nace como consecuencia de la Ley de Montes de 24 de mayo de 1863 , en la que se comienza por afirmar (artículo $1 .^{\circ}$ ) que

«los montes públicos, para los efectos de esta Ley, se dividen en las dos clases siguientes: 1.a Montes del Estado. 2." Montes de los pueblos y de los establecimientos públicos»

y se termina ordenando al Ministro de Fomento (artículo adicional $4 .^{\circ}$ ) que publique un Catálogo de los montes exceptuados de la venta, con arreglo a los artículos de dicha Ley.

Es sabido que la Ley desamortizadora de 1 de mayo de 1855 había declarado en estado de venta determinados bienes pertenecientes al Estado, al clero, a cofradías, a la beneficencia, a la instrucción pública, a los propios y comunes de los pueblos, etc., y que había exceptuado, entre otros, "los montes y bosques cuya venta no crea oportuna el Gobierno» (art. $2 .^{\circ}, 6 .^{\circ}$, de la Ley). En cuya virtud, el Real Decreto de 26 de octubre del mismo año divide los montes y bosques del Estado, de los propios y comunes y los de los establecimientos públicos, en las tres clases siguientes: 1..$^{\mathrm{a}}$ ) Montes que deben conservarse sujetos a las Ordenanzas del ramo y que se exceptúan de la enajenación; $2 .^{a}$ ) montes de enajenación dudosa, y $3 .^{a}$ ) montes que se declaran en estado de venta.

La Ley de 30 de agosto de 1896 disponía en su artículo 8. :

«Se procederá por el Ministerio de Fomento, de acuerdo con el de Hacienda, a la revisión y formación definitiva del catálogo de los montes que, por razones de utilidad pública, deban quedar exceptuados de la venta.»

Como se ve, aparecen aquí ya, por vez primera, la «utilidad pública» de los montes, como razón para ser excluidos de la venta.

Significativo es, a nuestro juicio, el contenido del artículo 14 de dicha Ley, por lo que respecta al objeto de nuestro estudio y por 
la trascendencia que pudo tener a efectos de conservación de los montes de los pueblos. Decía así dicho artículo:

«Se autoriza al Ministerio de Hacienda para que con sujeción a las prescripciones de la Ley de 8 de mayo de 1888, conceda a los pueblos un último y definitivo plazo para solicitar que se exceptúen de la desamortización los montes y terrenos de aprovechamiento común gratuito de sus vecinos y los que se hallen destinados al pasto de los ganados de labor. Esta autorización se refiere, no tan sólo a los pueblos que no hayan aún instruido sus expedientes, sino a los que, por cualquier concepto, les haya sido denegada la excepción».

En virtud de la revisión ordenada en la Ley que antecede, el Real Decreto de 1 de febrero de 1901 establecía en su artículo primero que

«los montes comprendidos en la relación que se acompaña constituyen el Catálogo de los exceptuados de la desamortización por causa de utilidad pública...».

Como hemos indicado en los antecedentes de este informe, el monte Vallerrutajo aparece ya, con el número 4, en el Catálogo aprobado por el citado Real Decreto, perteneciente «al pueblo de Carbonera».

En este primer período, por tanto, la relación de montes que constituye el Catálogo tiene como finalidad única la de exceptuar dichos montes de la desamortización, por razón o causa de utilidad pública.

El período siguiente, que se inicia ya a partir de la Orden de 11 de junio de 1908 (sobre deslindes) y del Decreto de 17 de octubre de 1925 (que contiene instrucciones para el régimen de los montes de los pueblos), se consolida con la Ley de 8 de junio de 1957.

En efecto, en aquellas normas ya no se habla del Catálogo como relación de montes exceptuados de venta, sino del "Catálogo de los Montes de Utilidad Pública», y en la Ley vigente de 1957 (artículo 6),

«el Catálogo de Montes es un registro público de carácter administrativo en el que se incluirán todos los montes que hubiesen sido declarados de utilidad pública pertenecientes al Estado, a las Entidades públicas territoriales y a los Establecimientos públicos de beneficencia o enseñanzan.

La declaración de utilidad pública, base de la inclusión, no es ya con fines desamortizadores, sino para someter los montes al 
régimen especial que regula la propia Ley —en virtud de lo dispuesto en el artículo $1 .^{\circ}$, núm. 4, apartado $a$ )—, como es, por ejemplo, la posibilidad de enajenación en determinadas condiciones formales, la presunción de posesión a favor de la Entidad pública a cuyo nombre figura, la obligatoriedad de inscripción en el Registro de la Propiedad, la práctica de deslindes, la posibilidad o no de mantener o establecer determinadas servidumbres, el aprovechamiento, conservación y mejora, la repoblación forestal, etc.

El monte Vallerrutajo, por figurar en el Catálogo de Montes de la Provincia de Logroño, es un monte declarado de utilidad pública.

\section{EN RAZÓN A SU PERTENENCIA}

A pesar de todas las vicisitudes por las que ha pasado la administración del monte Vallerrutajo, éste, a nuestro juicio, ha sido y es un bien de pertenencia municipal, de carácter patrimonial. Es la consecuencia a que llegamos una vez excluida la titularidad a favor del Estado y de particulares y teniendo en cuenta, por otro lado, que el monte no es un bien de dominio público (de uso o servicio público) -conforme a la clasificación de los artículos 183 de la vigente Ley de Régimen local y $2 .^{\circ}$ del Reglamento de Bienes de las Entidades locales-.

Que es un bien patrimonial municipal (más adelante veremos si de propios o comunal), lo vamos a intentar demostrar a través de los hechos que han marcado su propia evolución jurídico-administrativa.

\section{A) Inclusión en el Catálogo de 1901}

Hemos visto que en el mismo se atribuye su pertenencia «al pueblo de Carbonera».

¿Qué debemos entender por "pueblo»?

Desde luego, no podemos separar la palabra pueblo, que aislada puede tener - y de hecho tiene - significados distintos (racial o étnico -el pueblo español, el pueblo vasco-, político - la soberanía del pueblo, la justicia del pueblo-, geográfico —el pueblo de...-, social -conjunto de habitantes de un núcleo urbano-, sociológico —el pueblo como masa indiferenciada de gentes o como sector más discriminado...-, etc.), de la época histórica en que 
se usa y del contenido que en esa época le asignan las distintas disposiciones legales.

Del análisis de esa época y de su legislación llegamos a la consecuencia de que - a los efectos que esta legislación prevé- pueblo y Municipio se identifican (1).

Es posible que el concepto Municipio sea más moderno y elaborado que el de pueblo, y que aquél englobe a éste (2).

Pero es lo cierto, al margen de si el Municipio es entidad natural o no -cuestión ésta debatida por la doctrina y tratada distintamente por las diversas normativas locales-, que en la legislación de la segunda mitad del siglo pasado y aun en la del presente, pueblo y Municipio quieren expresar lo mismo: Ente local dotado de personalidad jurídica, que cuenta con órganos que le gobiernan y representan.

Un examen somero de la citada legislación nos prueba claramente el empleo indistinto de los conceptos pueblo, Municipio y Ayuntamiento (3):

- En la Ley de Montes de 1863 ya hemos visto que se habla de los «montes de los pueblos».

- El Reglamento de 17 de mayo de 1865 emplea también la denominación de "pueblos», pero claramente se aprecia que confunde pueblo y Municipio. Así, por ejemplo, en el artículo 48, cuando dice «el Gobernador oirá al Ayuntamiento del pueblo...», o el 81:

(1) Para un estudio sobre el origen y evolución del Municipio, sobre todo en relación con los montes (comunes-o públicos-, de propios y comunales), nos remitimos en bloque a la obra de Alejandro Nieto: Bienes comunales, Madrid, 1964, Editorial Revista de Derecho Privado.

(2) Marqúts Carbó (El Derecho local español, Barcelona, 1957, tomo I, pág. 2), al preguntarse qué es el Municipio, dice que hay que separar dos cosas que generalmente se mezclan indebidamente, dando lugar a errores de conceptos: el elemento social y el elemento jurídico. El social se ha creado espontáneamente; el jurídico, no: es un revestimiento exterior. Lo natural no es el Municipio, lo natural es el pueblo o ciudad. El pueblo o la ciudad existe por sí mismo. El Municipio lo ha creado el Estado. Así vemos cómo la Ley de 1877 dice explícitamente: «Se pondrá Municipio en los pueblos donde convenga que lo haya", lo cual demuestra, pues, que no es un concepto natural, sino legal, supeditado a los intereses o conveniencias de la administración del país.

(3) También MARquÉs CaRB6 -ob. cit., pág. 21-, para diferenciar el contenido de estas palabras, que parecen sinónimas y que no lo son, "y que aun en las propias leyes se utilizan indistintamente», define, con lenguaje-dice-comprensible para todos, dichos conceptos en la siguiente forma:

«Pueblo: Comunidad de hombres ligados por vínculos de tierra o espacio, familia, vecindad, trabajo, bienes e intereses, edificaciones, instituciones, empresas, etc.».

«Municipio: Personificación del pueblo o pueblos, a veces diseminados. Integración de los elementos: término municipal, población y poder, subordinado al Estado».

«Ayuntamiento: Organo supremo que dirige, gobierna y representa al Municipio». 
aLos montes de los pueblos y de Establecimientos públicos serán administrados bajo la vigilancia de la Administración superior por los Ayuntamientos o Corporaciones encargados de los Establecimientos, con arreglo a la Ley municipal y a las especiales por que estos últimos se rijan.»

- El Decreto de 17 de octubre de 1925, que contiene «instrucciones para el régimen de los montes de los pueblos", emplea todavía más indiscriminadamente los tres conceptos. Así tenemos:

«2. (...) la posesión de estos mismos montes se entenderá acre ditada por la simple inclusión en favor de la Mancomunidad, Municipio o Entidad local menor a quien el Catálogo asigne su pertenencia.»

«11. Si algún monte de la pertenencia de un pueblo...»

«39. Los acuerdos que adopten los Ayuntamientos autorizando la explotación en los montes de utilidad pública que les pertenezcan...»

«73. Los Ayuntamientos propietarios de montes declarados de utilidad pública...”

«79. (...) Si los Municipos de los pueblos y dueños de los montes de utilidad pública...»

«102. (...) previa la información de un expediente en que conste la petición bien justificada del Ayuntamiento del pueblo propietario...» «104. Se regulará por una disposición especial la forma como haya de practicarse la liquidación del 20 por 100 de propios y del 10 por 100 de aprovechamientos que los Ayuntamientos han de invertir en la repoblación de los montes de su pertenencia...»

«115. Lo dispuesto en las presentes instrucciones respecto a los Ayuntamientos será aplicable a las Mancomunidades y cualesquiera otras Entidades locales que sean propietarias de montes.»

El mismo empleo indistinto de conceptos nos lo da la redacción de los Estatutos de la fusión, donde observamos que los artículos $6 .^{\circ}$, 7., 10 y 11 se refieren al «pueblo de Carbonera», y los artículos 8.', 9. y 14 a «ambos pueblos» o «ambos pueblos de Carbonera y Bergasa», terminando los Estatutos así:

«En este estado quedan conformes ambos pueblos Ayuntamientos, aprobando los artículos expresados...»

Lo cierto es - repetimos- que pueblo y Municipio, en la citada legislación y en los Estatutos de la fusión, quieren decir lo mismo. Y que el citado Decreto de 17 de octubre de 1925, concretamente el artículo $2 .^{\circ}$ transcrito, nos confirma que el Catálogo asigna la pertenencia de los «montes de los pueblos» a una u otra de estas 
tres Entidades locales: Mancomunidad de Municipios, Municipio o Entidad local menor. No hay duda, por tanto, que la pertenencia del monte Vallerrutajo, según el Catálogo de 1901, corresponde al Municipio de Carbonera.

La prueba más defintiva de cuanto decimos, acreditativa de que la propia Administración del Estado ha entendido que son de pertenencia municipal los montes que el Catálogo de 1901 atribuía a los distintos «pueblos», está en que - al margen de la solución dada a Carbonera, de la que nos ocuparemos en su momento-, el Catálogo aprobado por Decreto 286/1977 asigna la pertenencia de esos mismos montes a los Ayuntamientos de aquellos «pueblos». (Lo que equivale a decir que si el Municipio de Carbonera no se hubiera fusionado con el de Bergasa, el monte Vallerrutajo figuraría hoy en este último Catálogo como de la pertenencia del Ayuntamiento de Carbonera.)

\section{B) Fusión de los citados Municipios}

Esta se realiza al amparo de los artículos 17 del Estatuto Municipal y 19 del Reglamento de Población y Términos Municipales.

En base, por tanto, a la facultad concedida por el primer artículo (las Corporaciones «concertarán libremente las condiciones de la unión, en cuanto a régimen de bienes y derechos patrimoniales o vecinales...») y cumpliendo lo preceptuado en el citado Reglamento, el Ayuntamiento y los vecinos de Carbonera solicitan en 1930 la fusión, condicionándola a que

ala administración de los bienes patrimoniales de ambos Municipios será por el de la capitalidad...»

y los Estatutos aprobados, en una redacción bastante defectuosa de su artículo $1 .^{\circ}$, atribuyen a la exclusiva competencia del Ayuntamiento de Bergasa, como hemos visto,

«la observancia de las leyes y aplicación de las mismas de conformidad por lo dispuesto en el artículo 150 del Estatuto Municipal vigente y dentro del mismo y siguientes...» (4).

(4) El citado artículo 150 preceptúa que es de la competencia del Ayuntamiento «el gobierno y dirección de los intereses peculiares de los pueblos, en la totalidad de su territorio, y en particular cuanto guarde relación con los objetos siguientes: 
Consecuentemente, si se pide la administración de los bienes patrimoniales y ésta se realiza exclusivamente por el Ayuntamiento de Bergasa, en uso de las atribuciones conferidas por los Estatutos de la fusión y por el Estatuto Municipal, está claro que al Municipio o al Ayuntamiento de Bergasa se le conceden las mismas perrogativas de administración sobre el monte Vallerrutajo que el Reglamento de Montes de 1865 atribuía a los Ayuntamientos sobre los «montes de los pueblos». Y si estos montes -en virtud del Decreto de 17 de octubre de 1925 y no existiendo Mancomunidad ni Entidad local menor- se entiende que pertenecen al Municipio, es evidente también que la pertenencia de dicho monte, después de la fusión, corresponde al Municipio de Bergasa.

La doctrina, en este punto, no puede ser más concluyente. CLAVERo ARÉvalo (5) dice que en la fusión se producen los siguientes efectos esenciales: $10^{\circ}$ Se extinguen todos los Municipios que se funden. $2 .^{\circ}$ Nace un nuevo Municipio con el territorio de todos ellos. 3. El nuevo Municipio sucede universalmente a todos los que se extinguen.

También, respecto de la integración de un Municipio a otro: 1. Se extingue el Municipio incorporado. $2 .^{\circ}$ No nace un nuevo Municipio. 3. Se verifica una cesión universal entre el Municipio incorporado y el incorporante.

LOPIZ VILA (6), al referirse al patrimonio, transcribe el dictamen de 13 de marzo de 1954 del Consejo de Estado (expte. 14.246), que dice: "La fusión implica unidad patrimonial, titular único del patrimonio municipal y unidad de sujeto en el orden jurisdiccional».

No hay duda, por tanto, que lo mismo si se trata de una fusión que de una incorporación, el nuevo Municipio de Bergasa resultante de la fusión (o el antiguo al que se incorpora el de Carbonera) es el titular - por sucesión o cesión universal- de los bienes pertenecientes al Municipio fusionado o incorporado. Sin que esta alteración modifique en absoluto la naturaleza jurídica del monte, que

25. Adquisición y enajenación de los bienes inmuebles y derechos reales $(\ldots)$.

26. Mejora, conservacion, custodia y aprovechamiento de los bienes indicados en el número anterior».

(5) «La situación de los funcionarios en los casos de alteración de términos municipales», en Estudios dedicados al profesor Gascón y Marín, Madrid, 1952.

(6) "La fusión e incorporación de Municipios en España», RevisTa DE Estudios DE LA VIDA LOCAL, núm. 162, abril-mayo-junio 1969, pág. 290. 
si era patrimonial municipal, perteneciente al Municipio de Carbonera - la inclusión en el Catálogo de 1901 no permite duda alguna a este respecto-, ahora, a partir de la fusión, sigue siendo patrimonial municipal, perteneciente al Municipio de Bergasa.

\section{C) Administración del monte a partir de 1930}

Incomprensiblemente, al margen de toda normativa o estipulación entre los Ayuntamientos fusionados, el monte Vallerrutajo no lo administra el Ayuntamiento resultante de la fusión, sino una Junta, cuya disolución se ordena gubernativamente en enero de 1962.

Es evidente que dicha Junta no actúa en representación de la Entidad local menor de Carbonera - que no se llegó a crear tras la fusión y cuya constitución fue denegada posteriormente por resolución del Consejo de Ministros de 15 de enero de 1955-, pese a que, en determinados momentos, actuara como tal y se reconociera de facto esta situación.

Evidente también que, de haberse constituido la Entidad local menor de Carbonera, el monte Vallerrutajo seguiría teniendo el carácter de bien patrimonial municipal, aunque, entonces, perteneciente a la citada Entidad local menor, pues tanto el Estatuto Municipal de 1924 (arts. 190-191) y la Ley municipal de 1935 (artículo $3^{\circ}$ ), como la vigente Ley de Régimen local (art. 125-1-b), atribuyen a estas Entidades la administración y conservación de sus bienes de propios y la regulación del aprovechamiento de los bienes comunales.

Ahora bien, si no existe Entidad local menor, ¿qué valor jurídico tiene la administración que - de hecho- realiza la citada Junta?

Desde luego Carbonera no ha sido una excepción, pues se conoce la existencia de Juntas que han administrado bienes para el disfrute exclusivo de vecinos agrupados alrededor de una determinada parroquia.

También es cierto que el Estatuto Municipal de 1924 y las leyes municipales posteriores no conceden a estas Juntas personalidad jurídica alguna.

La Jurisprudencia, sin embargo, no ha sido tan rígida. NIETo (7)

(7) $O b$. cit., págs. 465 y ss. 
cita la sentencia de 23 de abril de 1963, según la cual el Tribunal Supremo reconoce una cierta personalidad o cuasipersonalidad en la administración de bienes a estos núcleos no constituidos en Entidad local menor y matiza que, puesto que dicho Tribunal no se pronuncia sobre la titularidad dominical (extremo éste -afirmaaceptablemente aclarado en el artículo 22 del Reglamento de Montes), los efectos de esa cuasipersonalidad reconocida al núcleo social del anexo o parroquia son, sencillamente, «la posibilidad de atribuir la titularidad de los aprovechamientos a sus vecinos con exclusión de los demás vecinos del término municipal». En definitiva, añade, «los prolijos razonamientos del Tribunal Supremo lo que han hecho ha sido prestar una base dogmática a la declaración legal de los últimos párrafos del citado artículo 22 del Reglamento de Montes» (8).

Como se ve, aun existiendo la Junta parroquial o vecinal, el monte Vallerrutajo seguiría teniendo el carácter de bien patrimonial municipal, con la salvedad de que su titularidad se desglosaría así: La del dominio, que se atribuiría al Municipio de Bergasa, y la de los aprovechamientos, que la ostentarían los vecinos de la aldea o lugar o parroquia de Carbonera.

\section{D) Inscripción en el Registro de la Propiedad}

La inmatriculación del monte realizada en el año 1960, en base a certificación expedida por el Ingeniero Jefe de Montes del Distrito Forestal de Logroño y al amparo del artículo 11 de la vigente Ley de Montes, se realiza asignando su pertenencia o titularidad al mismo Ente o persona jurídica que figura en esa fecha en el Catálogo, o sea, «al pueblo de Carbonera».

Sin entrar ahora en si dicha inmatriculación es correcta, tenemos que interpretarla en los mismos términos y con la misma sig-

(8) Para mayor claridad del comentario de NiETo, transcribimos a continuación el texto del artículo 22 del Reglamento de Montes:

«En las inclusiones a que se refiere el artículo anterior, se asignará la titularidad a la Entidad local a la que pertenezca el núcleo de población que venga aprovechando el monte, haciendo constar que se practica la inclusión al amparo de lo dispuesto en el artículo cuarto, párrafo segundo, de la Ley de Montes, sin dejar de consignar la circunstancia de que el aprovechamiento del monte corresponde exclusivamente a los vecinos del núcleo de población de que se trata, aunque no esté legalmente constituido en Entidad local y todos estos extremos se transcribirán en la certificación que, en su día, se expida a efectos de la inscripción del monte en el Registro de la Propiedad». 
nificación que hemos dado a la titularidad o pertenencia del Catálogo. Debemos concluir, por consiguiente, que, según el Registro de la Propiedad, el titular del monte Vallerrutajo es el pueblo de Carbonera, o sea el Municipio de Carbonera, o sea su sucesor universal el Municipio de Bergasa. En definitiva, según el Registro, el monte es también un patrimonio municipal.

\section{E) Afirmación de los vecinos de Carbonera de que el monte es «vecinal en mano común»}

Esta afirmación, que es básica para comprender la actuación de dichos vecinos y que motiva la cesión realizada en 1976 a la Diputación, se justifica, a nuestro juicio, en una interpretación muy subjetiva de la frase "pueblo de Carbonera», titular del monte según el Catálogo (todavía en esa fecha regía el de 1901) y según el Registro de la Propiedad; en la resolución del Ministerio de Agricultura de 1 de septiembre de 1961, que desestimó la petición del Ayuntamiento de Bergasa sobre el cambio de titularidad dominical del monte; en el deseo - siempre patente- de que el monte sólo debían disfrutarlo los vecinos de Carbonera y en los preceptos sobre montes vecinales en mano común.

a) Respecto a la interpretación de la frase «pueblo de Carbonera", ya hemos visto que el Catálogo sólo incluía bienes pertenecientes a Entidades públicas y que en la terminología de la época «pueblo» equivalía a Municipio.

b) La resolución indicada del Ministerio de Agricultura la examinamos en otro lugar de este estudio.

c) El deseo de los vecinos de Carbonera de disfrutar en régimen de exclusividad el monte, es evidente desde la fusión de su Municipio con Bergasa. Ahí está, en demostración de ello, el funcionamiento del núcleo social como Entidad local menor o como mera Junta administrativa.

Ese deseo les ha llevado, erróneamente, a luchar contra el Ayuntamiento de Bergasa acerca de la titularidad o pertenencia del monte, en lugar de procurar afianzar en los Estatutos y en el propio Catálogo la titularidad a su favor de los aprovechamientos del monte. 
d) Desde el punto de vista de los preceptos sobre montes vecinales en mano común, ¿estaba justificada la afirmación anterior y la cesión realizada?

- Si tenemos en cuenta la Ley 52/1968, de 27 de julio (9), que regía en 1976, tenemos que contestar negativamente.

Es cierto que, al amparo del número 1 de su artículo $10^{\circ}$ (10) -en especial de la frase «con independencia de su origen», pues permitía eludir el examen de antecedentes que pudieran llevar hasta la verdadera naturaleza jurídica del monte y, por tanto, averiguar si las titularidades dominical y de los aprovechamientos concurrían o no en una misma persona jurídica- y, a la vez, en consideración a las circunstancias fácticas que se daban en la aldea de Carbonera después de la fusión de su Municipio con Bergasa (circunstancias ya apuntadas, tales como la constitución - no formal- de una Entidad local menor; la administración de los aprovechamientos del monte por su Junta vecinal y el refuerzo "moral» que supuso la repetida resolución del Ministerio de Agricultura), los vecinos de Carbonera hubieran podido instar la incoación del procedimiento para la clasificación del monte, conforme a lo dispuesto en el artículo 11 de la Ley. Decimos «hubieran podido» si aquellas circunstancias se hubieran mantenido con posterioridad, o sea si la comunidad vecinal hubiera continuado con la misma estructura y organización, con los mismos medios de vida y con similar número de miembros. Lo cual no quiere decir que, producida la clasificación, ésta nos pareciera correcta, pues reflejaba. meramente unos hechos que no tenían similitud con la administración del monte en el pasado ni resultaban de la clara aplicación de unos preceptos legales (11).

(9) Un comentario de esta Ley a cargo de NiETo en Revista de Administración Pública, núm. 57, págs. 351 y ss.

(10) Decía textualmente el citado número:

«Se regirán por las disposiciones de esta Ley los montes pertenecientes a los vecinos agrupados en parroquias, aldeas, lugares, caseríos, barrios y otros similares no constituidos formalmente en Entidades municipales que, con independencia de su origen, vengan aprovechándose consuetudinariamente en régimen de comunidad, exclusivamente por los integrantes de dichas agrupaciones en su calidad de miembros de las mismas, ya reciban la denominación de montes del común de los vecinos, montes vecinales, en mano común, forales u otras semejantes».

(11) Si, como dice Martín Mateo («El futuro de los bienes comunales», Revista DE EsTUDios DE LA VIDA LOCAL, núm. 155/1967, pág. 670), «los bienes vecinales re. presentan, pues, una pervivencia pura de las modalidades comunitarias dominicales de las épocas más antiguas», en el caso concreto de Vallerrutajo se habría invertido 
Pero hemos visto que la Junta administrativa que funcionaba hasta 1962 se disuelve por orden gubernativa; que los aprovechamientos se administran a partir de esa fecha por el Ayuntamiento de Bergasa (y se conceden después a la Diputación) y que, poco a poco, la comunidad vecinal de Carbonera se va extinguiendo lentamente.

La razón de esta extinción es doble: Por un lado, en Carbonera se produce también el fenómeno que se da en el resto del país: la despoblación de las zonas rurales y su migración a las ciudades. Las 25 familias que vivían en la primera mitad de los años sesenta se reducen a cuatro al comienzo de los setenta. Por otro lado, las tierras de propiedad particular se venden a personas o sociedades residentes en la capital, que ocupan, como trabajadores por cuenta ajena, a los únicos vecinos que todavía quedan en la aldea. En tales circunstancias, difícilmente podía pensarse que la Ley de 1968 era de aplicación al monte que nos ocupa.

Así lo debió entender también la Administración cuando, en uso de las facultades que otorgaba dicha Ley al Ministerio de Agricultura (art. 10-1), éste no creó en la Provincia de Logroño el «Jurado de Montes Vecinales en Mano Común», que era quien debía clasificar el monte y cuya clasificación, según el artículo $1 .^{\circ}$, número 2 , constituía requisito esencial y previo para que aquél quedase sometido a la repetida Ley e, incluso, para su exclusión del Catálogo (artículo 13).

En cualquier caso, los resultados de la clasificación - supuesta vigente la Ley 52/1968 - habrían sido prácticamente iguales a los conseguidos si el monte fuera de pertenencia municipal y calificado de "comunal», regido en este caso por la Ley de Régimen local y Reglamento de Bienes de las Corporaciones locales. Pues la Ley de 1968 no sólo asignaba a los Ayuntamientos funciones de tutela sobre los montes que regulaba (12), sino que, al referirse a su régimen jurídico en el artículo $2 .^{\circ}$, atribuía su titularidad y aprovechamiento a los vecinos, sin asignación de cuotas específicas (13),

este orden: de tener una naturaleza comunal (según tratamos de demostrar en este estudio) habría evolucionado después a un carácter vecinal, simplemente por inobservancia de preceptos legales o por actuaciones administrativas irregulares.

(12) Un resumen de las mismas en ABellán, Carmelo: Tratado práctico de la Administración Local Española, tomo II, Madrid, 1971, págs. 188 y 189.

(13) Según manifiesta NiETo en el comentario a esta Ley, ya citado (pág. 365), el contenido de este precepto «implica el reconocimiento de la figura jurídica de la 
y prescribía que eran bienes indivisibles, inalienables, imprescriptibles e inembargables.

Bien es cierto que, en este aspecto de la inalienabilidad, dicho precepto introducía una diferencia respecto ai 188 de la Ley de Régimen local, ya que éste no contiene excepción alguna - salvo si, conforme al 194, se produce la desafectación del uso comunal, a la que luego nos referiremos- y, sin embargo, aquél, excepcionalmente, permitía la cesión total o parcial, temporal o definitiva, a un Ente territorial. (Precepto en el que, sin duda, se basaron los vecinos para ofrecer la cesión a la Diputación.) Pero es también cierto que la decisión de ceder - sin validez alguna por no ir precedida de la clasificación del monte- hacía presumir de algún modo la extinción de la comunidad vecinal, el hecho incuestionable de que nadie de la misma se beneficiaba de los aprovechamientos correspondientes.

- Si contemplamos hoy la normativa vigente sobre montes vecinales en mano común, constituida por la Ley 55/1980, de 11 de noviembre (14), también debemos pronunciarnos sobre su in-

mano común o comunidad germánica, tal como estaba ya reconocido por la jurisprudencia y la doctrina».

El propio NiETo, en la repetida obra Bienes comunales, se refiere a este tema en sus capítulos VII (págs. 272/274) y IX (págs. 434/442), recogiendo la opinión de García Granero (pág. 272), según el cual las características propias de la mano común-que concurren en los aprovechamientos comunales-son: «a) los sujetos que disfrutan dichos pastos colectivos suelen, por regla general, estar unidos por un vínculo de carácter personal (relación de vecindad); b) el número de titulares es indeterminado y variable, de tal forma que el disfrute de los aprovechamientos se hace sin delimitación precisa, faltando la idea de cuota, al menos en el sentido romano del término; c) la ausencia de cuotas provoca la inalienabilidad; d) e incluso la intransmisibilidad de las mismas a los herederos, ya que se rige por normas especiales y no por las normales hereditarias; e) la comunidad es indisoluble».

(14) No es nuestro propósito en este estudio hacer un análisis de la Ley 55/80. Simplemente observamos, como novedades más destacadas respecto a la Ley 52/68, las siguientes:

- Desaparece la tutela del Municipio, como no sea para hacerse cargo del monte -temporalmente como administrador, y pasados treinta años como titular dominical del monte, ahora convertido en comunal-.

- Introduce la posibilidad de permuta entre terrenos de valor similar de montes colindantes de los regulados por la Ley. torial.

- Desaparece, como se indica en el texto, la cesión definitiva a un Ente terri-

- Es la propia comunidad vecinal la que, ante el órgano más inmediato de la justicia municipal, formalizará los Estatutos por los que habrá de regirse, en los que se regulará el derecho de los partícipes; los organos de representación, de administración o de gestión; la responsabilidad de los componentes y la impugnación de sus actos; el disfrute, uso o cesión de aprovechamientos; la participación en los de pastoreo, esquilmo y demás de percepción directa, etc.

- Mantiene la figura del Jurado-con distinta composición-y la necesidad de clasificación del monte, cuyos efectos son similares a los que producía la Ley de 
aplicabilidad al monte Vallerrutajo, en consideración, principalmente, a la razón expuesta de extinción de la comunidad vecinal. Pero es que, aun supuesta aplicable, la nueva Ley mantiene el carácter inalienable de estos montes, ahora sin la posibilidad de cesión definitiva - como excepción- a un Ente territorial.

\section{F) Inclusión en el Catálogo de 1977}

Hemos visto que en el Catálogo aprobado por Decreto 286/1977, de 21 de enero, el monte Vallerrutajo figura a nombre de "Carbonera, lugar del Municipio de Bergasa». (Más adelante analizamos las causas por las que se ha llegado a esta titularidad).

Ahora nos interesa determinar si aquél corresponde o no a una Entidad local. Pues bien: la mera inclusión en el Catálogo, conforme al artículo $6 .^{\circ}$ de la vigente Ley de Montes (que hemos transcrito), significa que el monte pertenece a una Entidad territorial, o a un establecimiento público de beneficencia o enseñanza. Descartado el Estado y la Provincia, como Entidades territoriales, así como la pertenencia a un establecimiento de beneficencia o enseñanza, sólo nos queda la titularidad a favor de una Entidad municipal. Sin embargo, el «lugar» de Carbonera no es Entidad local con personalidad jurídica reconocida por la Ley. ¿Cómo debe resolverse esta contradicción? A nuestro modo de ver, sólo de una manera: Si en el Catálogo de 1901 el monte era municipal -y seguiría siéndolo si no se hubiera realizado la fusión con Bergasa, de tal forma que en el Catálogo de 1977 figuraría a nombre del Ayuntamiento de Carbonera-y, por otro lado, no ha existido juicio declarativo de propiedad ante los Tribunales civiles (15), la inclusión del monte Vallerrutajo a favor de una Entidad sin persona-

1968, con la diferencia de reducir a la mitad el plazo (a partir de adquirir firmeza la resolución del Jurado) para rectificar las inmatriculaciones contradictorias del Registro de la Propiedad.

- Señala con más claridad y detalle los cometidos de la Administración respecto a los montes que regula.

- Incluye la denuncia al Ministerio Fiscal de actos que atentan o ponen en peligro la conservación o la integridad de los montes, para el ejercicio por aquél de las acciones civiles y penales adecuadas.

- Sustituye los órganos de la Administración Central por los de las Comunidades Autónomas, a partir de la transferencia a las mismas de las correspondientes com. petencias.

- Somete a determinadas normas los negocios jurídicos realizados sin intervención de la comunidad titular del monte.

(15) Artículo 11-6 de la vigente Ley de Montes. 
lidad jurídica sólo puede interpretarse como un error, que debe ser subsanado atribuyendo el monte al Ente municipal con jurisdicción en la aldea o lugar de Carbonera, o sea, al Municipio de Bergása.

Creemos, a través de cuanto queda expuesto, que está suficientemente demostrado que el monte Vallerrutajo es un bien patrimonial perteneciente al Municipio de Bergasa.

\section{Por RAZón DE SU DESTiNo O APROVEChaMiento}

Hemos visto que los preceptos de la vigente legislación local divide los bienes patrimoniales de los Entes locales en dos grupos: de propios y comunales. Son los primeros

«los que siendo propiedad del Municipio no estén destinados al uso público ni a la realización de ningún servicio y puedan constituir fuente de ingreso para el Erario municipals (art. 186 de la Ley de Régimen local).

\section{Son bienes comunales}

«los de dominio municipal, cuyo aprovechamiento y disfrute pertenece exclusivamente a los vecinos» (art. 187).

Demostrado que el monte Vallerrutajo es un bien patrimonial municipal, nos corresponde ahora determinar si es un bien de propios o, por el contrario, es un bien comunal.

Desde luego nos faltan muchos datos y documentos, unos en relación con sus orígenes y otros respecto a la explotación en cada una de las etapas, pero, en cualquier caso, no parece aventurado afirmar el carácter de bien comunal del monte Vallerrutajo.

La naturaleza jurídica de los montes comunales está suficientemente estudiada por la doctrina (16) y por la jurisprudencia (17).

(16) Principalmente por GarRido Falla, Fernando-«Sobre los bienes comunales», REVISTA DE EsTUDIOS DE LA VIDA LOCAL, núm. 125, septiembre-octubre 1962-, y Nieto-Bienes...-. Aquél habla de un tertium genus (pág. 675) y éste de la titularidad concurrente y compartida, de «concurrencia de pretensiones jurídicamente distintas sobre un mismo objeto" (pág. 271). También analiza la naturaleza del derecho de los vecinos («derecho real administrativo de goce», pág. 286) y la diferencia existente entre estos montes, que califica de comunales típicos, de los comunales atípicos (páginas 301 y sigs.).

(17) La sentencia de 14 de junio de 1968 (también comentada por NieTo- «Bienes comunales: Refundición del dominio forestal de suelo y vuelon, Revista de $A d$ ministración Pública, núm. 60, 1969-) dice en uno de sus considerandos 
Ahora bien: Para ratificar o rectificar este juicio inicial, nada mejor que examinar la distinta situación histórica por la que ha atravesado el monte.

\section{A) Vicisitudes hasta la década de los años sesenta}

a) Hemos visto anteriormente que la Ley de 30 de agosto de 1896 ordena la revisión y formación definitiva del Catálogo y se concede un último y definitivo plazo a los pueblos para solicitar que se exceptúen de la desamortización «los montes y terrenos de aprovechamiento común gratuito de sus vecinos y los que se hallen destinados al pasto de los ganados de labor». Parece lógico pensar que uno de estos montes, incluido en el Catálogo de 1901, sea el que nos ocupa.

Díaz Caneja, después de afirmar que de la clasificación, definición y régimen legal de bienes municipales, lo más deficiente es los mal llamados «comunales» (que él considera "comunes») y de justificar sus discrepancias con la definición legal, se refiere a que nuestras leyes municipales siguen guardando silencio casi absoluto sobre la circunstancia de hallarse o no clasificados y catalogados como de utilidad pública determinados montes municipales. $\mathrm{Y}$ termina sobre este punto diciendo: «Dejamos aquí constancia

«que la naturaleza propia de aquellos bienes sobre los que tiene lugar un aprovechamiento común o vecinal gratuito, y que 'pertenecen' a las Entidades locales (...), debe resolverse sin pretender identificar a todo trance la cuestión relativa a los beneficiarios con la referente a la titularidad dominical, ya que al ser sustituido aquel concepto por los de Municipio y vecinos, ninguno de ambos deben ser considerados como titulares exclusivos de las relaciones jurídicas que hacen referencia a los bienes comunales, sino como titulares concurrentes, en una titularidad simultánea, según la doctrina recogida en la Resolución de la Dirección General de los Registros de 3 de junio de 1927 (...), encontrándose ante una titularidad compartida, que viene atribuida de modo diverso entre partícipes cualitativamente diferentes, $\mathrm{y}$ ante una propiedad cuyo contenido es el aprovechamiento o disfrute, quedando anulada o esfumada la vertiente dominical del ius disponendi, ya que su esencia no es la disposición de los bienes, sino solamente su aprovechamiento o disfrute por los miembros de la comunidad, de modo que el derecho de 'participar de los aprovechamientos comunales', citado en el artículo 47 de la Ley de Régimen Local (...), puede configurarse como un derecho real administrativo de goce, a la vez que pertenecen al Municipio los bienes sobre los que recae, como una variedad de los patrimoniales, y son de dominio municipal, a tenor de lo establecido en los artículos 82, 183 y 187 de la LRL, debiendo incluirse en el Catálogo de Montes 'a favor de la Entidad local cuyo núcleo de población venga realizando los aprovechamientos', según los artículos $4 .^{\circ}$ de la Ley y 21 y 22 del Reglamento de Montes». 
de que los montes catalogados eran y son generalmente comunes, aunque la legislación especial lo silencia y haya hecho caso omiso de ello» (18).

b) Los Estatutos de la fusión de los Municipios, redactados en febrero de 1930, no mencionan al monte Vallerrutajo. Desconocemos la razón, que podría ser doble: una, el hecho de estar catalogado y, por tanto, sujeto a control e intervención administrativa (que se hacía notar principalmente, según el Decreto de 17 de octubre de 1925, en la redacción de planes dasocráticos, en las subastas de los productos de los montes, en la repoblación forestal, etc.). Otra, el recelo de los vecinos de Carbonera - sin duda motivado por la deficiente regulación entonces de los montes comunales (19) - de que, al fusionarse con Bergasa, podrían disfrutar de los aprovechamientos del monte la totalidad de vecinos del nuevo Municipio. Poco hubiera costado -insistimos- que se incluyese una cláusula en los Estatutos, salvando el derecho exclusivo de los vecinos de Carbonera a tales aprovechamientos, aunque la administración correspondiera al Ayutamiento de Bergasa o, caso de constituirse Carbonera en Entidad local menor, a la Junta vecinal correspondiente.

En cualquier caso y además de algunas referencias poco claras que contienen los artículos 2. ("fusión de toda clase de pastos»), 8. (obligación de "no roturar los terrenos de ninguna especie en todo el territorio que comprenda la demarcación de las jurisdicciones fusionadas») y 12 («siempre que haya aprovechamiento de pastos, la villa de Bergasa tendrá la obligación de avisar a la aldea de Carbonera"), hay que remitirse a la declaración general del artículo $1 .^{\circ}$, que, a su vez, nos lleva al artículo $150 \mathrm{y}$ siguientes del Estatuto Municipal. Pues bien, el artículo 153-6 de este Estatuto establece que corresponde al Ayuntamiento Pleno

«la determinación, distribución y aprovechamiento de los montes comunales...».

c) En la declaración jurada que Carbonera eleva al Distrito Forestal en 1938 sobre el monte Vallerrutajo, suscrita por el Secre-

(18) Díaz Caneja, José D. y: «Bienes municipales», Revista de Estudios de LA VIDA LOCAL, núm. 81, mayo-junio 1955 , págs. 431/436.

(19) NieTo, en el comentario a la Ley de 27-7-68, citado, decía que use ha desperdiciado una magnífica, probablemente única, oportunidad de promulgar una Ley de montes comunales, incluyendo dentro la variedad de vecinales» (pág. 353). 
tario con el visto bueno del Presidente de la Entidad (donde se lee "término municipal de Carbonera» y «Entidad local menor o parroquia de idem» - lo que justifica en cierto modo la aseveración apuntada en otro lugar de que tanto la Administración forestal como el Ayuntamiento de Carbonera seguían ignorando la existencia de la fusión con Bergasa-), se hace constar, textualmente, lo siguiente:

«Pertenencia: de la Entidad.

Condominio: no existe.

Servidumbre: no tiene.

Naturaleza jurndiva: declarado de utilidad pública y de aprovechamiento común con el número 4 del Catálogo de la Provincia.

Principales aprovechamientos: leñas.»

¿Puede haber una prueba más clara y concluyente de que el monte en 1938 era comunal?

d) En las Actas de las reuniones celebradas por la Asamblea vecinal, presidida por el Alcalde pedáneo, se aprecia la misma calificación jurídica. Concretamente, en la de 20 de abril de 1960, se da cuenta de que han quedado desiertas dos subastas de aprovechamientos extraordinarios de leñas del monte "Vallerrutajo", acordándose por unanimidad «adjudicarlas directamente para el pueblo». La Junta después propone, "viendo y comprendiendo que al pueblo le basta con las leñas autorizadas para consumo de hogares en dicho monte», ceder aquellos aprovechamientos extraordinarios gratuitamente a un vecino de Ocón por su buen comportamiento en el acarreamiento de materiales con su camión a obras realizadas en el pueblo y en el monte.

En algunos aprovechamientos que en esta época concede el Distrito Forestal se aprecia que aquéllos se refieren a pastos y leñas, tanto en subasta como «vecinales». No hay duda tampoco, por consiguiente-cualquiera que sea el régimen de los aprovechamientos, conforme a lo dispuesto en los artículos 192 de la Ley de Régimen local y 77 y siguientes del Reglamento de Bienes-, que en el período siguiente a la fusión y durante los primeros años sesenta, el monte seguía teniendo la naturaleza jurídica de bien comunal. 


\section{B) Destino del monte hasta nuestros dias}

No poseemos datos suficientes sobre los aprovechamientos ordinarios o extraordinarios señalados por el Distrito Forestal o el ICONA, sobre la entidad administradora de los mismos (inmediatamente después de desaparecida la Junta Administrativa lo fue el Ayuntamiento de Bergasa) y sobre la participación que los vecinos de Carbonera han podido tener en dichos aprovechamientos.

Ahora, a partir de la cesión realizada por los vecinos a la Diputación, se conceden a ésta dichos aprovechamientos, y en los escritos correspondientes, se habla todavía de aprovechamiento de pastos «vecinal».

Una cosa sí parece evidente: La emigración de los vecinos y su ausencia del núcleo urbano de Carbonera está produciendo una desafectación del destino comunal del monte.

A este respecto, el Reglamento de Bienes de las Entidades locales establece en su artículo $8 .^{\circ}$, número 5 , lo siguiente:

«Se entenderá, asimismo, producida, sin necesidad de acto formal, desafectación de los bienes de dominio público y de los comunales, que se convertirán en bienes de propios, cuando hubieren dejado de utilizarse durante veinticinco años en el sentido de la afectación pú. blica o comunal.»

El mismo Reglamento-siguiendo el criterio del artículo 194 de la Ley de Régimen local-dispone en su artículo 83-1:

«Cuando por su naturaleza o por otras causas los bienes no hubieren sido aprovechados comunalmente durante más de diez años, aunque en alguno de ellos existieran actos aislados de disfrute, podrán ser desprovistos del carácter de comunales y considerados de propios, mediante el procedimiento que señala el artículo 8 y previo dictamen favorable del Instituto Nacional de Colonización.»

Como se ve, el apartado $5 \mathrm{del}$ artículo $8 .^{\circ}$ no exige acto formal alguno, sólo el transcurso de veinticinco años, mientras que el 83, pasados ya diez sin aprovechamiento comunal, posibilita la desafectación mediante el procedimiento que señala el mismo artículo $8 .^{\circ}$ en sus apartados 1 y 2 (20).

(20) Esta materia de la desafectación de bienes o montes comunales ha sido estudiada ampliamente por Nieto (Bienes..., págs. 495 y sigs.) y por REBes Solé («Desafectación de los montes comunales por no uso de sus aprovechamientos», REVISTA DE Estudios DE LA VIDA LoCAL, núm. 151, 1967, págs. 59 y sigs.). 
Seguido o no el procedimiento de desafectación, el monte Vallerrutajo camina hacia su conversión en un bien patrimonial de propios.

Lo que ocurre es que éste y los demás bienes resultantes de la desafectación no son iguales a los demás bienes de propios, por cuanto los citados preceptos, concretamente los artículos 194-2 de la Ley de Régimen local y el 83-2 del Reglamento de Bienes-este último con una matización importante-, disponen que deberán ser arrendados para su aprovechamiento agrícola, con preferencia a los. vecinos o cabezas de familia del Municipio. La matización indicada consiste en que sólo procederá el arrendamiento agrícola si los bienes «no fueran susceptibles de otra utilización más adecuada, a juicio de la Jefatura del Distrito Forestal».

Estos preceptos han sido duramente criticados por NIETo, llegando a decir, refiriéndose a ejemplos concretos que, «en estos casos, la interpretación debe ponerse al servicio de la lógica o de la necesidad, y no encerrarse en un riguroso (y cómodo, por descontado) respeto a la Ley, más propio de rábulas y de burócratas adocenados que de auténticos juristas» (21).

\section{EXAMEN DE LAS ACTUACIONES ADMINISTRATIVAS HABIDAS A PARTIR DEL EXPEDIENTE DE FUSION}

\section{INSCRIPCión DEL MONTE EN El Registro DE LA PROPIEDAD}

Desde un punto de vista formal, dicha inscripción es correcta, puesto que transcribe íntegramente la pertenencia que el Catálogo de 1901, vigente en 1960, asigna al monte Vallerrutajo.

Nos sorprende únicamente que el Registrador de la Propiedad, en el ejercicio de su función calificadora (22), no tuviera en cuenta lo siguiente:

Que el peticionario de la inscripción, Alcalde pedáneo de Carbonera, actuaba sin representación legal alguna, habida cuenta de que la constitución de Carbonera como Entidad local menor había sido denegada en 1955.

Que el hecho de estar incluido en el Catálogo de Montes de Utilidad Pública suponía-conforme al repetido artículo 6 de la Ley

(21) Bienes..., pág. 511.

(22) Reconocida en los artículos 18 y 19 de la vigente Ley Hipotecaria. 
de Montes-que el monte pertenecía a una Entidad local (en 1901 y hasta 1930, Municipio de Carbonera) y, sin embargo, al inmatricularlo a favor del "pueblo de Carbonera», lo hacía a favor de un ente sin personalidad jurídica, puesto que desde 1930, la representación de ese "pueblo», entendido como comunidad, la jurisdicción sobre él, entendido como territorio, correspondía al Municipio de Bergasa.

\section{Resolución del Ministerio de Agricultura de 1 DE SEPTIEMBRE DE 1961}

En los antecedentes de este estudio hemos indicado que la citada resolución se basa en los argumentos de Carbonera, y principalmente en los informes de la Abogacía del Estado y de la Jefatura del Distrito Forestal. A continuación reseñamos sucintamente dichos argumentos e informes y exponemos nuestro criterio sobre los mismos.

\section{A) Argumentos de Carbonera}

a) «La Dirección General de Montes, en 1934, deniega al Ayuntamiento de Bergasa petición sobre aprovechamientos forestales, haciendo constar que Carbonera está en la posesión absoluta del predio".

En realidad, el criterio de la Dirección General en esa fecha nos confirma más bien la naturaleza jurídica de bien comunal del monte y el carácter exclusivo de sus aprovechamientos.

E imaginamos que llega a ese criterio no sólo ignorando totalmente la fusión, sino teniendo en cuenta preferentemente la literalidad de la inscripción en el Catálogo ( $y$, por tanto, la pertenencia que el mismo atribuye al monte) y lo dispuesto en la normativa vigente en esa fecha, como era el Reglamento de 17 de mayo de 1865, cuyo artículo 11 establece:

«Mientras no sean vencidos en el juicio competente de propiedad, el Estado, los pueblos y las Corporaciones administrativas que se hallen en posesión de un monte, se mantendrá ésta por el Gobierno y por los Gobernadores, como si no se hubiese deducido reclamacion alguna.»

Pero una cosa es la posesión del monte, que se presume a favor de la Entidad a cuyo nombre se halla inscrito en el Catálogo, y otra 
el derecho de los vecinos-derecho real administrativo de goce; derecho público de naturaleza corporativa; derecho, en suma, que emana de la condición de vecino (23)—, que debe ser respetado, regulado y administrado por el propio Ayuntamiento (24).

Significativa es, a este respecto, la sentencia de 23 de marzo de 1957, que al referirse al derecho de reparto, aprovechamiento y disfrute de unos determinados vecinos sobre un monte, manifiesta en uno de sus considerandos que

«constituye ciertamente un beneficio que, al recaer sobre los aludidos vecinos por su calidad de tales y sin designación nominativa ni individual, que implicaría una concesión a los mismos como particulares, revela sin duda alguna que los referidos derechos, anexos al concepto de vecindad, se hallan comprendidos en la esfera de los correspondientes a los partícipes del Municipio y han de ser regulados por la Entidad rectora que los representa y dirige, la cual es el Ayuntamientos.

De ahí que aun cuando la denegación fue correcta, se debió basar en el derecho exclusivo de goce que sobre el monte tenían los vecinos de Carbonera y no en la posesión de Carbonera, que, como Municipio, era inexistente. Puesto que la posesión-como sucesor universal de aquél, en virtud de la fusión acordada-se debía presumir ya a favor del Municipio de Bergasa (25).

b) «El cambio de titularidad debe resolverse en la jurisdicción ordinaria».

Es cierto que las cuestiones sobre pertenencia de un monte catalogado o cualquier otra de carácter civil (26) deben suscitarse antela jurisdicción ordinaria una vez agotada la vía administrativa, o sea, efectuando reclamación previa a la vía judicial civil. Pero a:

(23) NiETo: Bienes..., págs. $286 / 288$.

(24) El artículo 47 de la vigente Ley de Régimen local reconoce este derecho. en los siguientes términos:

«Los cabezas de familia y los vecinos tendrán derecho a participar de los aprovechamientos comunales y de otros beneficios concedidos al pueblo, y estarán sujetos a las cargas que para fines de Administración central o. local impongan las leyes».

(25) No creemos que en el repetido criterio de la Dirección General de Montes influyera la redacción del artículo 310 del Estatuto Municipal entonces vigente-que posibilitaba la titularidad de estos bienes al común de vecinos y que hoy, a tenor del artículo 5. del Reglamento de Bienes, pertenecen a las Entidades locales-, por cuanto, como queda dicho, la posesión de los montes catalogados se presumía «en favor de la Mancomunidad, Municipio o Entidad local menor a quien el Catálogo asigne su pertenencia» (art. 2 del Decreto de 17-10-1925, transcrito en el texto del informe).

(26) Artículos 42 y 55 a 60 del vigente Reglamento de Montes. 
nuestro modo de ver, no estamos ante una cuestión de cambio de titularidad, sino ante una absorción o fusión de pertenencias operada ope legis, con motivo de la fusión acordada entre Carbonera y Bergasa. Estamos ante la "desaparición» legal de una Entidad y ante la "creación" de otra que se hace cargo, por ministerio de la Ley, de los bienes de aquélla. No hay, por tanto, cambio de titularidad, sino «sucesión» legal de dicha titularidad, que debe aceptarse sin más trámite por la Administración. Y es contra dicha sucesión de la titularidad, operada por mandato legal y aceptada por la Administración, contra la que, de no estar conformes, tendrían que haber reclamado ante la jurisdicción ordinaria los vecinos de Carbonera.

Creemos poder afirmar que muchas de las cuestiones que se han suscitado en relación con determinados montes catalogados, se deben al hecho de que en el propio Catálogo no aparece reflejada desde la inscripción su naturaleza de bienes comunales (27). En estas circunstancias, poco habría importado que la titularidad dominical del monte Vallerrutajo la «heredase» el Municipio de Bergasa, si los aprovechamientos seguían vinculados a los vecinos de Carbonera. Pero no ha sido así, y al discutirse sobre aquella titularidad, en realidad se estaba defendiendo el aprovechamiento vecinal del monte.

c) «El lugar de Carbonera tiene personalidad jurídica para seguir siendo el propietario y titular del monte, dado que es un bien patrimonial».

Aquí se produce otra vez la misma confusión: Efectivamente, el monte es patrimonial (en este caso, comunal), y por serlo, debe estar atribuido a una Entidad local con personalidad jurídica, que sólo tiene el Municipio de Bergasa y no la aldea o lugar de Carbonera. Este sí pudo tener-reconocida por la jurisprudencia, según hemos examinado anteriormente-cierta personalidad para administrar los aprovechamientos de su comunidad.

d) «Siendo patrimonial no puede cambiar su titularidad, por su carácter de inalienable, conforme a la legislación de montes y de régimen local».

Con esta afirmación, los propios vecinos de Carbonera están demostrando la naturaleza comunal del monte, porque sólo mien-

(27) El artículo 39-2 del repetido Reglamento de Montes dice que, entre otros datos de los montes, se expresará también en el Catálogo «su clasificación como bienes de propios o comunales». 
tras conserve esta naturaleza, el monte es inalienable, imprescriptible e inembargable (28). Y aquí también se vuelve a confundir cambio de titularidad o enajenación, por «sucesión» de esa titularidad.

e) «La fusión no implica más que jurisdicción, pero no la administración ni mucho menos la pertenencia».

Otro error: La fusión implica, repetimos, la absorción de los bienes de los Municipios fusionados por el nuevo Municipio resultante de la fusión. Y, por tanto, la pertenencia. Lo que no tenía que implicar necesariamente era la administración por el nuevo Municipio de los bienes de los Municipios fusionados o del incorporado, pues, al amparo de lo dispuesto en el artículo 19 del Reglamento sobre Población y Términos Municipales de 2 de julio de 1924, este extremo podía haberse previsto en la propia instancia de petición de la fusión y, desde luego, en los Estatutos. Pero hemos visto que éstos nos remiten a los artículos 150 y siguientes del Estatuto Municipal y, por tanto, atribuyen la administración-aunque luego en la práctica no fue así-al Ayuntamiento de Bergasa.

f) «El nombramiento de Alcalde pedáneo lo hace el Gobierno Civil».

Esta cuestión es intrascendente y únicamente revela que durante algún tiempo Carbonera, de hecho, se organizó como si, de derecho, estuviera constituida en Entidad local menor.

\section{B) Argumentos de la Abogacía del Estado}

a) «Bergasa no justifica la posesión».

A nuestro modo de ver, Bergasa, heredero del Municipio de Carbonera por ministerio de la Ley, no tiene que justificar posesión alguna. Si ésta (y también la pertenencia o titularidad), en virtud de lo dispuesto en la legislación de montes (29), se presume a favor del "pueblo de Carbonera» (o sea, del Municipio de Carbonera), también debe presumirse a favor del sucesor legal de aquél. La posesión-no el disfrute del monte, que eso ha sido evidente-tendrian que haberla justificado los vecinos de Carbonera, pero hemos podido comprobar que ya desde 1934, a partir prácticamente de la fusión, se confunde titularidad dominical con titularidad del apro-

(28) Artículos 188 LRL, 94 Reglamento de Bienes y $64-3$ Reglamento de Montes.

(29) Artículo 1 (R. D. 1-2-1901), 2 (D. 17-10-1925), 10 (L. 8-6-1957) y 65 (Reglamento 22-2-1962). 
vechamiento, posesión con derecho real administrativo de goce. En tales circunstancias, fácil es presumir erróneamente que aprovechamiento equivale a posesión.

Pero ni ello es así, ni así lo entiende tampoco el Tribunal Supremo. La sentencia de 8 de abril de 1959, con toda claridad, manifiesta que

«los bienes comunales no pueden ser poseídos a título de dueño por los vecinos del Municipio a que pertenecen, los cuales sólo pueden ejercitar actos de simple aprovcehamiento o disfrute, o sea que esta mera tenencia natural sólo circunscribe poder a los vecinos sobre tales bienes en cuanto a las ventajas económicas que les reportan, pero que está muy lejos de encubrir un verdadero estado posesorio civil, por faltar el animus, o sea la intención de poseer en concepto de dueño conjuntamente con el transcurso del tiempo (...). Es un caso análogo al arrendatario o al precarista que posee en nombre del dueño y que jamás puede por este título llegar a ostentar la titularidad dominical del bien disfrutado...».

b) «La fusión no es suficiente para privar al conjunto de habitantes que integran el lugar de Carbonera de la titularidad del monte».

No nos vamos a extender más sobre este tema, pues está suficientemente tratado y siempre gira sobre lo mismo, sobre la naturaleza comunal del monte. El argumento, por tanto, sería perfecto si se hubiera expresado así: "La fusión no es suficiente para privar al conjunto de habitantes que integran el lugar de Carbonera del disfrute exclusivo del monte».

\section{C) Argumentos de la Jefatura del Distrito Forestal}

«Debe mantenerse la posesión, en tanto no sea vencida en juicio competente la Entidad a cuyo favor figura la inscripción».

Tampoco vamos a detenernos en ello, pues sería repetir nuevamente los argumentos anteriores, empleados en rebatir los expuestos por Carbonera y por la Abogacía del Estado, contenidos en la resolución del Ministerio de Agricultura que nos ocupa.

\section{Cesión del monte a la Diputación Provincial}

Los hechos y circunstancias relatados (la administración del monte llevada a cabo por los vecinos después de la fusión, las 
actuaciones administrativas habidas en evitación de que la titularidad del monte se asignara al Municipio de Bergasa y aun la propia inmatriculación registral realizada por el Alcalde pedáneo de Carbonera) pudieron hacer creer a los vecinos de Carbonera que, además del disfrute del monte, les correspondía su titularidad dominical.

Nadie comprendió en su momento que el monte-dada su naturaleza comunal-podía pertenecer a un Municipio y, a la vez, corresponder su disfrute exclusivamente a determinados vecinos. Ello hizo que éstos, presumiéndose titulares y atribuyendo al monte un carácter («vecinal en mano común») que, a nuestro juicio y como hemos intentado demostrar, no tiene, cedieran a la Diputación la propiedad del mismo en determinadas condiciones de afectación; que el Ayuntamiento de Bergasa accediera a los deseos de los vecinos, "ya que son titulares del citado monte»; que la Diputación aceptara la cesión; que el Ministerio de Agricultura no tuviera inconveniente en la misma; que el Ministerio del Interior se declarase incompetente en el expediente incoado para la correspondiente autorización, y que el Notario de Arnedo, en base al artículo 2 de la Ley de Montes, comunique que no hay posibilidad alguna de llevar a efecto tal cesión, lo que parece indicar, interpretando dicho precepto, que la cesión pretendida requeriría el respaldo de una ley.

Hoy, después de realizado el presente estudio, tenemos que decir que los vecinos de Carbonera no pueden realizar la cesión del monte, ni $\tan$ siquiera mediante ley, porque no son titulares dominicales del mismo. Tampoco podrían realizarla en el supuesto de que lo fueran, si el monte se clasificaba como "vecinal en mano común", por su carácter de inalienable, en virtud de lo dispuesto en el artículo $20^{\circ}-1$ de la Ley 55/80.

\section{Pertenencia o titularidad del monte Según el Catálogo de 1977}

Extinguido el Municipio de Carbonera al fusionarse con el de Bergasa y desestimada por el Ministerio de Agricultura la petición de este último Municipio sobre el cambio de titularidad o pertenencia del monte (en realidad, repetimos, más que cambio era simplemente una "sucesión» legal de dicha titularidad), no quedaba otro camino a la Administración que mantener la inscripción de 1901. 
Pero como ello significaba continuar en el nuevo Catálogo con una redacción ya suprimida ("pueblo de...»), pues ahora los bienes se iban a atribuir a los Ayuntamientos y no a los pueblos, y, por otro lado, manteniendo aquella redacción se podía interpretar que seguía existiendo el Municipio de Carbonera, se optó por la fórmula de atribuir el monte a la misma localidad, Carbonera, pero añadiendo «lugar del Municipio de Bergasa». Con ello se cumplía la resolución del Ministerio de no permitir la inscripción del monte a favor del Ayuntamiento de Bergasa (lo que, para nosotros, es un error) y, a la vez, se cometía uno nuevo, cual era el atribuir su pertenencia a un ente sin personalidad jurídica alguna.

\section{INClusión DEL monte EN EL INVENTARIo de Bienes DE La Diputación}

Si el Ayuntamiento de Bergasa no hace valer el derecho que, según nuestro criterio, tiene sobre el monte y si los aprovechamientos del mismo se conceden por el ICONA a la Diputación, ésta, en su día-pasados treinta años si el monte es de propios o pasado el mismo período, pero contado a partir de la desafectación comunal de aquél (30)-, podrá considerar prescrito a su favor el dominio, puesto que habrá poseído el monte en concepto de dueño desde el momento de la cesión e inclusión en el Inventario de Bienes (31).

Los inconvenientes de este procedimiento son claros: Lesiona intereses legítimos de un Municipio y, por falta de titularidad, no permite la formalización de convenios con el ICONA para la mejor explotación del monte o para el establecimiento del parque comarcal a que se refieren los vecinos de Carbonera en el escrito de cesión y que, en cierto modo, condiciona la misma.

(30) Conforme a los números 1 y 3 del artículo 64 del Reglamento de Montes.

(31) La sentencia de 28 de octubre de 1975 , entre otras, reconoce también que "la inclusión de un monte en el Catálogo no es óbice para el juego de la prescripción adquisitiva a favor de terceros...». y sigs.

Sobre este tema de la prescripción, véase también Niero (Bienes...), págs. 543 


\section{SOLUCIONES QUE SE PROPONEN}

\section{PROCEDIMIENTO PARA MOdificar LA titUlaridad \\ O PERTENENCIA DEL MONTE}

\section{A) En el Catálogo de Montes de Utilidad Pública}

Anteriormente, al comentar los argumentos expuestos por Carbonera oponiéndose a que el Municipio de Bergasa fuera el titular del monte, hemos sostenido el criterio de que la petición de este Municipio no pretendía un cambio de titularidad, sino tan sólo que el Catálogo adaptase los datos registrales a la "sucesión» que en esa titularidad se había operado ope legis.

Hoy, después que el Catálogo de 1977 atribuye-a nuestro juicio erróneamente-la pertenencia del monte Vallerrutajo a «Carbonera, lugar del Municipio de Bergasa», no tenemos más remedio que opinar que la corrección de ese error supone realmente un cambio de titularidad, y que este cambio sólo puede realizarse a través del procedimiento que señalan los artículos 42 y 55 a 60 del Reglamento de Montes vigente, o sea:

a) Reclamación previa a la vía judicial civil, suscrita por el Alcalde de Bergasa en nombre y representación de su Ayuntamiento, dirigida al Ministerio de Agricultura y presentada en la Jefatura Provincial del ICONA, acompañando los documentos justificativos de aquélla y un croquis del monte.

b) Audiencia a la Entidad interesada (¿qué órgano representa actualmente a la aldea o lugar de Carbonera?).

c) Oposición de esta Entidad, en cuyo caso queda expedita la vía judicial o allanamiento de la misma, lo que originará el envío del expediente a la Dirección General de lo Contencioso del Estado. «Esta-según MASA ORTIZ-, dentro de los dos meses siguientes a la entrada del expediente, elevará al Ministro de Agricultura el proyecto de Orden resolutoria-art. 140, número 3, de la Ley de Procedimiento administrativo— $\longrightarrow(32)$.

(32) Masa Ortiz, Miguel: Legislación de Montes, Barcelona, Ediciones Nauta, 1964, pág. 102.

En la misma página se añade: «Si la Administración no notificare su decisión en el plazo de tres meses, el interesado podrá considerar desestimada su reclamación, al efecto de formular la correspondiente demanda judicial-artículo 141 LPA $\longrightarrow$. 
d) Demanda, si esta Orden es desestimatoria, ante la jurisdic- . ción ordinaria (33).

A nuestro modo de ver, el Ministerio de Agricultura no debe poner serios obstáculos a la modificación que, en su caso, solicite el Ayuntamiento de Bergasa.

Si en otra ocasión (34) ha permitido que unos montes particulares pertenecientes a una agrupación de vecinos de una localidad cambiaran la titularidad a favor del Ayuntamiento de esa localidad, conservando aquéllos su aprovechamiento, simplemente porque así lo pidieron tales vecinos al Alcalde, con mayor razón en este caso, donde la titularidad no se ha desvinculado nunca del Ente municipal (llámese Carbonera, llámese Bergasa-sucesor de aquél-), sencillamente porque no ha existido transmisión legal alguna que tal hecho posibilitara.

\section{B) En el Registro de la Propiedad}

a) Si la Orden ministerial estima la reclamación del Ayuntamiento de Bergasa y acepta que el monte pertenece, como consecuencia de la fusión, a este Municipio, creemos que bastará la simple comunicación de aquélla para adaptar el Registro a la nueva situación, dado que, repetimos, al figurar en el Registro que el monte pertenece «al pueblo de Carbonera» y ser el Municipio de Bergasa el nuevo titular-por ministerio de la ley-de los bienes que antes pertenecían a los pueblos de Carbonera y Bergasa, no se produce un cambio de titularidad, sino una sucesión legal de dicha titularidad. En nuestra opinión, el acuerdo de fusión de ambos Municipios y su publicación en la Gaceta de Madrid, más el reconocimiento de sus efectos por el Ministerio de Agricultura, debe operar en el Registro lo mismo que si se tratase de un testamento o un contrato sucesorio (35).

(33) Sería, en este caso, como reanudar la actuación municipal alli donde quedo paralizada en 1964 - ante las puertas del Juzgado de Primera Instancia de Logroño-, en virtud de la sentencia de la Sala de lo Civil de la Audiencia Territorial de Burgos de 26-9-1964.

(34) Véase la sentencia del Tribunal Supremo de 26-5-1967.

(35) Artículo 14 de la Ley Hipotecaria de 8-2-1946.

Entendemos que no es de aplicación el procedimiento de rectificación a que se refiere el artículo 40 y concordantes de dicha Ley, por cuanto los supuestos de inexactitud que contempla no tienen nada que ver con el que planteamos, pues más que de rectificar una determinada inscripción, se trata de adecuar la existente a la modificación operada en virtud de la aplicación de un precepto legal de régimen local. 
b) Si la Orden ministerial desestima la reclamación indicada, entonces habrá que estar a lo que resulte del juicio declaratorio correspondiente, sustanciado ante la jurisdicción ordinaria.

\section{C) En el Inventario de Bienes de la Diputación}

No habiéndose formalizado la cesión en escritura pública, el mero acuerdo que adopte la Diputación, de oficio o a instancia del Ayuntamiento de Bergasa, si rectifica o anula el de aceptación de la cesión por estimar que los vecinos de Carbonera no están legitimados para realizarla, bastará para excluir el monte Vallerrutajo del citado Inventario.

En otro caso, la exclusión o no del Inventario provincial dependerá del resultado de la actuación del Municipio de Bergasa ante el Ministerio de Agricultura y ante la jurisdicción ordinaria, en el supuesto de que opte por la defensa de sus presuntos derechos.

\section{OPCIONES POSTERIORES}

Supuesto que este Municipio opte, en primer lugar, por la citada defensa de sus derechos, y supuesto además que consiguiera su objetivo-el de obtener de una manera formal la titularidad dominical del monte-, todavía le quedaría decidir respecto a los siguientes extremos:

\section{A) Desafectación o no del carácter comunal del monte}

Dado el escaso número de vecinos que viven en Carbonera, si se acredita que éstos llevan más de diez años sin el disfrute o aprovechamiento de sus productos, parece aconsejable la incoación de expediente, al amparo del artículo 8, números 1 y 2, del Reglamento de Bienes, para obtener la desafectación del monte y convertirlo en bien patrimonial municipal de propios.

Si el Ayuntamiento optare por mantener el carácter comunal del monte, decidiendo extender su disfrute-ante la falta de utilización por los de Carbonera-a todos los vecinos del término municipal, sería conveniente estudiar la fórmula más idónea para que los aprovechamientos tuvieran la mayor rentabilidad posible (36).

(36) Sobre este punto escribe Martín Mateo (ob. cit., págs. 680/681) lo siguiente: «Ahora bien, en estos momentos estamos ante una economía de mercado medida de- 


\section{B) Destino del monte}

Una vez desafectado, en su caso, y convertido el monte en bien de propios, suponiendo-dadas sus características-que el aprovechamiento agrícola sea el menos indicado, deberá destinarse aquél a la utilización que juzgue más adecuada el ICONA (conforme al ya citado artículo 83-2 del Reglamento de Bienes), ponderando sus posibilidades forestales, las de creación de un parque comarcal, las de compaginar ambos usos $\mathrm{u}$ otras de interés general.

Decidida la creación del parque comarcal, el Ayuntamiento podría optar por la cesión del monte a la Diputación (37) o simplemente por la formalización de un convenio con dicha Entidad y el ICONA.

\section{CONCLUSIONES}

De lo expuesto, y en síntesis, podemos formular las siguientes:

1. ${ }^{\text {a }}$ El monte Vallerrutajo, catalogado de utilidad pública, es un bien patrimonial municipal de carácter comunal.

2. ${ }^{\text {a }} \quad$ La titularidad dominical del mismo corresponde al Municipio de Bergasa-como sucesor legal del de Carbonera-, y la de sus aprovechamientos, a los vecinos de esta aldea o lugar.

3. ${ }^{a}$ Consideramos errónea la pertenencia que el Catálogo de 1977 asigna al monte Vallerrutajo.

4. ${ }^{\text {a }}$ Una serie de actuaciones administrativas irregulares, que, a la vez, motivaron una situación de hecho en la administración del monte, han podido cambiar su naturaleza jurídica-de comunal

finitivamente por valores monetarios. Ha surgido, además, con un ímpetu arrollador un fenómeno de organización económica: la empresa. La regulación de los bienes comunales debe, pues, acompasarse a estos nuevos condicionantes.

No se trata de propugnar su desnaturalización, sino, por el contrario, acomodar su intrínseca sustancia colectiva a las exigencias contemporáneas... Por ello se sugiere que la explotación productiva se haga hoy no fragmentaria y antieconómicamente, sino de acuerdo con fórmulas sensibilizadas a los caracteres de la explotación agrícola moderna. En este sentido parece que la cooperativa constituye el cauce idóneo y la respuesta actual a las esencias a que los bienes comunales responden...".

(37) En este caso, la cesión del monte-previa su conversión en bien de propios-, por aplicación de lo dispuesto en el artículo 4 de la Ley de Montes (que somete los montes del Catálogo, en cuanto se refiere a las Entidades locales, a la Ley de Régimen local), no necesitaría el requisito formal de una Ley, sino que se tramitaría con sujeción a lo dispuesto en los artículos $189 \mathrm{LRL}$ y $95 \mathrm{RB}$, con las modificaciones introducidas por el R. D. 1710/1979, de 16 de junio. 
a vecinal en mano común-, en el supuesto de que la comunidad vecinal no se hubiera extinguido.

5. ${ }^{\text {a }} \quad$ cesión del monte realizada por los vecinos de Carbonera a favor de la Diputación Provincial no tiene validez, por cuanto, por su carácter comunal, el monte es inalienable. (También sería inalienable hoy si tuviera el carácter de «vecinal en mano común», en virtud de lo dispuesto en la nueva Ley 55/80.)

6. ${ }^{\mathrm{a}}$ El Ayuntamiento de Bergasa tiene argumentos jurídicos suficientes para intentar-por vía administrativa y judicial, en su caso-el cambio de titularidad a su favor en el Catálogo de Montes de Utilidad Pública y en el Registro de la Propiedad.

7. $\quad$ Recobrada la titularidad del monte, podrá optar entre mantener su carácter comunal o desafectarlo para convertirlo en bien de propios. En este caso, suponiendo inadecuado su aprovechamiento agrícola, el ICONA informará sobre las posibilidades de explotación más racional. y eficiente del monte (forestal, parque comarcal, etc.). Para la creación del parque comarcal, el Ayuntamiento podría ceder el monte a la Diputación o suscribir convenio con esta Entidad y el ICONA. 
REVISTA

DE

ESTUDIOS

(ais겅 DE IA

$\Longrightarrow$ VIDA LOCAL

\section{CRONICAS}


REVL-1981, núm. 210. NASARRE ALASTRUEY, RAFAEL. TITULARIDAD Y NATURALEZA JURIDIC... REVL-1981, núm. 210. NASARRE ALASTRUEY, RAFAEL. TITULARIDAD Y NATURALEZA JURIDIC... 